ROCZNIKI TEOLOGICZNE

Tom LXVIII, zeszyt $8-2021$

DOI: https://doi.org/10.18290/rt21688.4

TIMOTHY P. O'MALLEY

\title{
THE LITURGICAL OFFERING OF BOREDOM
}

\begin{abstract}
A b s t r a c t. Is there such a thing as a boring rite, or is boredom instead an affective experience of a subject? This article argues that nothing-including the post-conciliar rites of the Church—can be intrinsically boredom. Rather, boredom-or more clearly the refusal to undergo boredom - is a spiritual sickness of late modernity. The article begins with an analysis of the phenomenon of boredom with a particular focus on boredom in a digital ecology. The article then turns to the symptoms of boredom as examined by social and cultural theorists over the last decade including Zygmunt Bauman, Harmut Rosa, and Byung-Chul Han. Lastly, the article examines Romano Guardini's The Spirit of the Liturgy as providing a medicine against the kind of anti-festive culture that is the source of boredom in late modernity. Boredom is not a problem with a rite but with the self who has not yet learned to participate in the serious playfulness of the act of worship.
\end{abstract}

Keywords: liturgy; culture; festivity; boredom.

Boredom is an ambiguous phenomenon for the religious person. ${ }^{1}$ On the one hand, boredom is a threat to the life of prayer, a temptation to give in to acedia or listlessness. The bored monk is uninterested in chanting the psalms, fatigued by mumbling the same texts day-after-day. On the other hand, boredom can open a horizon toward a deepening of prayer. The happy religious is not overly concerned about a certain kind of boredom or dryness, recognizing it as an invitation to prayerful obedience, a fruitful aridity that draws one closer to God. ${ }^{2}$

Timothy P. O'MALLEY is the director of education at the McGrath Institute for Church Life and academic director of the Notre Dame Center for Liturgy; e-mail: tomalley@nd.edu

${ }^{1}$ Michael L. Raposa, Boredom and the Religious Imagination (Charlottesville, VA: University of Virginia Press, 1999).

${ }^{2}$ Teresa of Avila, The Way of Perfection, trans. Kieran Kavanaugh and Otilio Rodriquez 
In either case, boredom is a phenomenon experienced by a subject. The human person must reconfigure his or her desires to meet the challenge of spiritual tedium. And yet, the liturgical scholar Dr. Peter Kwasniewski has recently argued that boredom is not a subjective matter but a fundamental characteristic of the reformed rites of the Second Vatican Council. ${ }^{3}$ The Novus Ordo, according to Kwasniewski, is by its very nature boring, and only the Traditional Latin Mass can quench the thirst of the ennui-plagued late modern subject.

And yet, can a rite be intrinsically boring? The argument of this essay is that it is unsound to characterize anything-rite or not-as boring. Boredom is a spiritual malaise of the modern era rather than intrinsic to a particular activity. ${ }^{4}$ This essay first offers a brief account of the phenomenon of boredom as experienced by the late modern subject immersed in a digital ecology. The essay then turns to the modern malaise of boredom as a cultural phenomenon marked by liquidity, speed and a desire for control, and an amnesia relative to festivity. If we experience the Novus Ordo as an occasion of boredom, the task ahead of us is a re-attunement of the desires of the human person, who may learn to fruitfully offer even this boredom unto God. ${ }^{5}$ The liturgical medicine offered by Romano Guardini in his The Spirit of the Liturgy continues to possess a salutary effect, especially relative to the reformed liturgy of the Second Vatican Council.

\section{THE PHENOMENON OF BOREDOM}

What is boredom? As Fr. Nicholas Lombardo writes, "Boredom is a subtle emotional state, hard to pin down, and it eludes easy classification. Being bored is unpleasant, but not exactly painful, either. When we are bored, it is not that we feel any positive emotional distress; rather, nothing engages us about what we are doing." ${ }^{\circ}$ As an affective phenomenon, boredom is linked to tedium. And yet, boredom is not entirely noxious-as is true of all affec-

(Washington D.C.: Institute for Carmelite Studies, 2000).

${ }^{3}$ Peter Kwasniewski, Reclaiming Our Roman Catholic Birthright: The Genius and Timeliness of the Traditional Latin Mass (Brooklyn, NY: Angelico Press, 2020).

${ }^{4}$ Nicholas E. Lombardo, OP, “Boredom and Modern Culture," Logos 20.2(2017): 36-59.

5 Timothy P. O’Malley, Bored Again Catholic: How the Mass Could Save Your Life (Huntington, IN: Our Sunday Visitor, 2017).

${ }^{6}$ Lombardo, "Boredom and Modern Culture," 37. 
tions - if the subject knows how to respond. A child, bored while on a long journey in a car, can find ways to occupy her attention through attending to the world outside the vehicle, allowing the imagination to play over the course of the journey. Boredom is often an engine for creativity and thus human flourishing if the person remains attentive to the world around her. ${ }^{7}$ We can adjust our own attitude toward any activity, adopting an autotelic and thus playful posture. As the psychologist Mihaly Csikszentmihalyi writes, "Any activity, then, will be experienced as rewarding if it allows one to use his sensory and physical potential in a novel or challenging way." 8

Technology has attenuated our capacity to respond to boredom in a fruitful way. If we find ourselves bored during our commute to work, the ubiquity of smart phones serves as a mediator of distraction. Rather than discerning meaning in a specific activity, we turn our attention to the Internet. As the cultural commentator and journalist Nicholas Carr writes: "The Net commands our attention with far greater insistency than our television or radio or morning newspaper ever did. Watch a kid texting his friends or a college student looking over the roll of new messages on her Facebook page or a businessman scrolling through his emails on his BlackBerry... What you see is a mind consumed with a medium. When we're online, we're often oblivious to everything else going on around us. The real world recedes as we process the flood of symbols and stimuli coming through our devices." 9 The increasing sense of both boredom and anxiety in late modern life is fostered through this profitable-at least for tech companies-addiction to mindless scrolling. Companies profit through promoting distraction, moving us from link to link, article to article, so that advertisers can mine our data. ${ }^{10}$

The late modern person, formed in this posture toward reality, will find most things that require consistent attention boring. Many novels are far from tedious, and still students are unable to devote attention to the act of reading any text beyond the length of a tweet. The digital world has habituated us to turn toward our phones at the very moment when we feel the initial pangs of disengagement.

\footnotetext{
${ }^{7}$ Peter Toohey, Boredom: A Lively History (New Haven: Yale University Press, 2011).

${ }^{8}$ Mihaly Csikszentmihalyi, Beyond Boredom and Anxiety: Experiencing Flow in Work and Play (San Francisco: Jossey Bass, 1975), 25.

${ }^{9}$ Nicholas Carr, The Shallows: What the Internet Is Doing to Our Brains (New York: W.W. Norton \& Company, 2011), 117-18.

${ }^{10}$ Shoshana Zuboff, The Age of Surveillance Capitalism: The Fight for a Human Future at the New Frontiers of Power (New York: Public Affairs, 2019).
} 
Figures like Dr. Peter Kwasniewski ignore this social and cultural context in their presumption that the Novus Ordo liturgy is intrinsically boring. Likely, those who attend the Extraordinary Form do find the liturgy more engaging and thus less boring than parishioners in a local parish celebrating the rites of the Second Vatican Council. Catholics who seek out the Extraordinary Form are likely counter-cultural, going against the grain of a society obsessed with digital engagement. They attend the Extraordinary Form liturgy as a way of expressing deeper engagement in Catholic faith, and therefore are more likely to commitment themselves to robust liturgical practice in the first place. ${ }^{11}$ If every parish in the United States or Poland required an exclusive celebration of the Extraordinary Form tomorrow, then one would likely hear cries of boredom from the digital addicts who attend Mass in a typical parish on a Sunday.

The phenomenon of boredom, therefore, is not intrinsically linked to any activity that a human being may perform. Sewing may not be your cup of tea, but it is meaningless to say, "Sewing is always and absolutely boring." To the novice and master seamstress alike, sewing can be an occasion of immense pleasure. Boredom in a modern key is a cultural phenomenon, a refusal to commit oneself to an activity that may not be immediately pleasurable. And if we are to initiate Catholics into a liturgical identity, we must attend more closely to the culture that makes us eschew boredom as an invitation to enter more deeply into the practice of prayer.

\section{BOREDOM AS AN ANTI-FESTIVE CULTURE}

Sociologists have begun to attend more closely to the phenomenon of boredom or ennui that defines much of late modern life in a digital age. Boredom or ennui is closely related to the impermanence characteristic of late modernity, and it influences the capacity for liturgical contemplation. ${ }^{12}$ In his work, Liquid Times, the Polish sociologist Zygmunt Bauman describes how the late modern person approaches progress. He writes: "«Progress», once the most extreme manifestation of radical optimism and a promise of universally shared and lasting happiness, has moved all the way to the oppo-

\footnotetext{
${ }^{11}$ Stephen Bullivant, Mass Exodus: Catholic Disaffiliation in Britain and American since Vatican II (New York: Oxford University Press, 2019).

12 Timothy P. O’Malley, "Liturgical Memory and Liquid Modernity," Antiphon 22(2018): 121-137.
} 
site, dystopian and fatalistic pole of anticipation: it now stands for the threat of a relentless and inescapable change that instead of auguring peace and respite portends nothing but continuous crisis and strain and forbids a moment of rest. Progress has turned into a sort of endless game of musical chairs in which a moment of inattention results in irreversible defeat and irrevocable exclusion. Instead of great expectations and sweet dreams, "progress' evokes an insomnia of nightmares of 'being left behind'—of missing the train, or falling out of the window of a fast accelerating vehicle". ${ }^{13}$

Bauman describes this liquidity as possessing a psychological effect upon the human person. We have been trained in a liquid attitude, such that the self is complete not through stability or commitment but through constant movement from activity to activity, from place to place, and from person to person. ${ }^{14}$ There is nothing solid including social bonds, vocation, and our individual affections. We are formed to consume, and the consumer is never permanently attached. One must learn to be “...'ever ready', of having the ability to rise to the opportunity as it comes, to develop new desires made to the measure of new, previously un-heard of and unexpected allurements...not to allow the established needs to render new sensations redundant or to restrain the capacity to absorb or experience them." ${ }^{15}$ In this situation, it is almost impossible for any man or woman to be happy. The Augustinian restlessness of the human heart is made into a monster, urging us to cultivate desire not for God but for its own sake. Restlessness is evidence of human flourishing, of having achieved the kind of happiness promoted in magazines and self-help quizzes. There is no sustained mission of the human person in a liquid culture. Any commitment that we adopt must be left behind if selffulfillment requires it. ${ }^{16}$

The speed at which this liquid culture moves is part of the problem. The sociologist Hartmut Rosa has described how our perception of temporality has changed in late modernity. He writes, "Since the heightening of the pace of life should be understood as a result of the scarcity of time resources... subjectively it is expressed in the growing sense that one lacks time or is pressed for time and in a stressful compulsion to accelerate as well as in anxiety

\footnotetext{
${ }^{13}$ Zygmunt Bauman, Liquid Times: Living in an Age of Uncertainty (Malden, MA: Polity Press, 2007), 10-11.

${ }^{14}$ Zygmunt Bauman, Liquid Love: On the Frailty of Human Bonds (Malden, MA: Polity Press, 2003), 1-37.

15 Zygmunt Bauman, Liquid Modernity (Malden, MA: Polity Press, 2012), 77.

${ }^{16}$ Zygmunt Bauman, The Art of Life (Malden, MA: Polity, 2008), 41-43.
} 
about "not keeping up." 17 The average shelf-life of a smart phone is no more than two years. A company releases a new mobile device, which promises a better camera, more memory, and a richer palette of colors. Yet, the phone lasts for but a moment, replaced by its successor. The happiness we enjoyed by possessing that smart phone fades away. As an individual subject, I can barely keep up with the new products I must purchase, the skills I must cultivate to be relevant in social life, and the growth needed to be successful in the labor market.

Rosa notes that this subjective addiction to accelerating progress cultivates the human person in an acquisitive posture toward the world. He writes, "Our life will be better if we manage to bring more world within our reach: this is the mantra of modern life, unspoken but relentlessly reiterated and reified in our actions an behavior... Always act in such a way that your share of the world is increased - has become the dominant principle behind our decisionmaking in all areas of life and across all ages, from toddlers to the elderly." ${ }^{18}$ Because progress is normative, and speed defines every aspect of life, it is assumed that the human person has infinite control over every aspect of existence. The world is at our fingertips, we imagine, if only we seize it. If I am unhappy in work or love, the task before me is not self-reflection but changing the world around me. Who has time for unhappiness, when there are products to purchase, vacations to experience, and life to enjoy? The more that I control the world, the more experience I can acquire.

Rosa notes that this approach to life is ultimately self-defeating. We cannot control every aspect of existence. The COVID-19 pandemic has re-presented this reality to us. Despite our planning (even recognizing that our planning could have been better), the world includes viruses that can wreak havoc upon the human immune system. Our best science cannot eliminate every one of these viruses, and at times, we may need to slow down the inevitable march of consumer progress that has become the measure of a successful society for the sake of the common good. Human happiness involves attuning ourselves to that which is not controllable-birth and death, sickness and love. He writes, "Where 'everything is under control,' the world no longer has anything to say to us, and where it has become newly uncontrolla-

${ }^{17}$ Hartmut Rosa, Social Acceleration: A New Theory of Modernity, trans. Harmut Rosa (New York: Columbia University Press, 2015), 79.

${ }^{18}$ Hartmut Rosa, The Uncontrollability of the World, trans. James C. Wagner (Malden, MA: Polity, 2020), 11. 
ble, we can no longer hear it, because we cannot reach it." ${ }^{19}$ Rosa speaks about the experience of resonance that takes place in that which we cannot control. If we recognize that a pandemic has come, putting an end to the inexorable march of progress, we are open to learning from what the pandemic could teach us if we possess the ears to hear. We are receptive to meaning that comes to us as gift. Our happiness is dependent on our posture within the world, how we approach the uncontrollable. It is not a matter of affection alone but a certain way of abiding, closely attentive to the way that existence gives itself to us. Not everything in the world will resonate with us, and yet that is the gift of life. As Rosa comments, "To desire that all our relationships to the world be resonant is also to overlook the fact that...an irreducible aspect of inaccessibility is inherent in all resonant experiences. ${ }^{20}$ In this case, boredom may not be a meaningless experience but an opportunity to await the gift that is to come from the world. Raising children does not mean constant movement of the affections or infinite excitement. But commitment to the practice of parenthood will mean that we experience such resonance in the lives of our children and spouse alike not through control but through keeping vigil before the world that gives itself to us. ${ }^{21}$

Resonance requires a posture of festivity in the world, creating space for the world to give itself to us as that which may be contemplated in joy. ${ }^{22}$ And yet, late modern life is marked by a refusal to take up a festive disposition in the world. Yes, there is the pursuit of pleasure, of both leisure and aesthetic experiences that enable us to escape the workaday world. ${ }^{23}$ But it is the world of work that defines the meaning of life. Rest is for the sake of increasing productivity. The philosopher Byung-Chul Han argues that our refusal to rest is the origin of secularity: "If rest becomes a form of recovery from work, as is the case today, it loses its specific ontological value. It no longer represents an independent, higher form of existence and denigrates into a derivative of work. Today's compulsion of production perpetuates work and

\footnotetext{
${ }^{19}$ Ibid., 116.

${ }^{20}$ Hartmut Rosa, Resonance: A Sociology of Our Relationship to the World, trans. James C. Wagner (Malden, MA: Polity, 2020), 172.

${ }^{21}$ See Jean-Yves Lacoste, Experience and the Absolute: Disputed Questions on the Humanity of Man, trans. Mark Raftery-Skehan (New York: Fordham University Press, 2004), 75-98.

22 Josef Pieper, In Tune with the World: A Theory of Festivity (South Bend, IN: St. Augustine's Press, 1999).

${ }^{23}$ Byung-Chul Han, The Burnout Society, trans. Erik Butler (Stanford: University of Stanford Press, 2015).
} 
thus eliminates that sacred silence. Life become entirely profane, desecrated." ${ }^{24}$ If life becomes about productivity, then the festival disappearance. The human person is not looking to enter the stillness of existence, of a time that transcends productivity. The loss of festival time is also the sacrifice of narrative and thus alike. Again, Han writes: "The religion of Christianity to a large extent narrative. Festivals such as Easter, Whitsun and Christmas are key narrative moments within an overall narrative which provides meaning and orientation. Every day is given a narrative tension, is made meaningful, by the overall narrative. Time itself becomes narrative, that is, meaningful." ${ }^{25}$ In a non-liturgical world, time is simply experienced as passage. Boredom and tiredness alike are regular phenomena, and the only possible response is to escape the present moment through pursuing the kind of resonant experiences identified by Rosa. But once more, resonance becomes an occasion of acquisition rather than openness to gift. The mundane world remains trapped in its mundaneness, never becoming full of possibility, of any horizon beyond the now.

In an anti-festive culture, it is not surprising that liturgy-Novus Ordo or Extraordinary Form-would be experienced as boring. Liturgical time is cyclical, not progressive. One never moves beyond the celebration of the enfleshment of the Word at Christmas or the hymns of praise of Pascha. Liturgical progress does not mean changing around the rite once every decade but allowing the rite to shape the self over the course of time. Liturgical reform, in the present era, may be dominated by a desire for control. We believe that if we get the "rite" precisely correct, then every problem in the Church and society will disappear at once. We fail to recognize that the liturgical problem par excellence is not the rite but the subject who is uncomfortable with festive time, looking instead for aesthetic experiences of resonance.

The anti-festive quality to late modern life can entrench itself into the reformed rites of the Second Vatican Council perhaps more easily than in the Extraordinary Form. Celebrants can forget the need for silent contemplation in the Eucharistic liturgy, speeding the rite along so that the assembly can get back to the work of the day. Rather than let the language of signs speak for themselves, what we might call a contemplative posture, the presider of the

\footnotetext{
${ }^{24}$ Byung-Chul Han, The Disappearance of Rituals, trans. Daniel Steuer (Malden, MA: Polity Press, 2020), 39.

25 Ibid., 44.
} 
Eucharistic liturgy feels the need to speak endless words to explain the ritual. In such speech, the narrative quality of the liturgy dissipates. Festivity is replaced by technical explanation, by the language of the workforce rather than worship.

Ritual change will not end this anti-festive culture. Rather, liturgical formation - the attunement of the self into a liturgical being-is still the primary task of the post-conciliar period. How can boredom itself become the liturgical offering that we make in the Eucharistic liturgy?

\section{RESTORING FESTIVITY}

In this short essay, it is impossible to provide a comprehensive medicine for healing an anti-festive culture that eschews any moment of salutary boredom, a stillness that invites deeper engagement with the ritual acts of the Church. ${ }^{26}$ And yet, in the remaining section of this essay, I turn to Romano Guardini's classic The Spirit of the Liturgy as providing a program for liturgical formation that can restore a festive culture.

Guardini's The Spirit of the Liturgy is written as a response to an idolatry of a world obsessed with technique, speed, and power. ${ }^{27}$ Throughout Guardini's The Spirit of the Liturgy, he emphasizes that liturgical prayer is not about producing or controlling resonant experiences in the worshipper. $\mathrm{He}$ writes: "[...] the liturgy is wonderfully reserved. It scarcely expresses, even, certain aspects of spiritual surrender and submission, or else it veils them in such rich imagery that the soul still feels that it is hidden and secure. The prayer of the Church does not probe and lay bare the heart's secrets; it is as restrained in thought as in imagery; it does...awaken very profound and very tender emotions and impulses, but it leaves them hidden... We can pour out our hearts, and still feel that nothing has been dragged to light that should remain hidden." 28

Liturgical prayer-if it is to be true, good, and beautiful-is never an aesthetic exercise for those interested in the affections generated by a Pale-

\footnotetext{
26 The author of this essay is working on a monograph on this tentatively entitled, On Praise: Liturgical Renewal in Late Modernity.

27 See Romano Guardini, Letters from Lake Como: Explorations in Technology and the Human Race (Grand Rapids, MI: Eerdmans, 1994).

${ }^{28}$ Romano Guardini, The Spirit of the Liturgy, trans. Ada Lane (New York: Crossroads, 1998), 27-28.
} 
strina motet or the poetics of a Latin collect. The truth of the rite, that is God's activity in the liturgical act, is the raison d'etre of all Christian worship. Guaradini writes, "Beauty eludes those who pursue it for its own sake, and their life and work are ruined because they have sinned against the fundamental order of values." ${ }^{29}$ Liturgy is an encounter with a real God who comes to save a sin-sick human being, and only then is the liturgical act supremely beautiful. ${ }^{30}$

Of course, liturgy speaks through the language of both symbol and play. The liturgy is symbolic in its use of the material order. Guardini writes, "A symbol may be said to originate when that which is interior and spiritual finds expression in that which is exterior and material." ${ }^{31}$ Delighting in a liturgy necessitates a contemplative disposition that looks with wonder upon the material and ritual world of the rite. That is, liturgical contemplation requires time, a willingness to be festive. As Guardini describes in his work Sacred Signs about incense: "The offering of an incense is a generous and beautiful rite. The bright grains of incense are laid upon the red-hot charcoal, the censer is swung, and the fragrant smoke rises in clouds. In the rhythm and the sweetness there is a musical quality; and like music also is the entire lack of practical utility; it is a prodigal waste of precious material. It is a pouring out of unwithholding love". ${ }^{32}$ Liturgical formation does not commence with explanation but with beholding. Perhaps, the post-conciliar liturgy is unnecessarily boring when the liturgist does not invite the worshipper to behold the full symbolic world of the liturgy. The anti-festive culture desires speed so incense, song, stained glass, and a decorated altar is passed over as excessive and unnecessary for the efficacy of the rite. This passing over is not intrinsic to the Novus Ordo but is a symptom of the very same cultural malaise that Guardini identified in the 1920s well before the reforms of the Second Vatican Council.

The liturgy is also playful. This playfulness does not mean that the Christian operates without rules when celebrating the liturgy. Rather, Guardini notes that liturgy is playful because of the object of focus in the liturgical act: "In the liturgy man is no longer concerned with himself; his gaze is directed towards God...The liturgy means that the soul exists in God's pre-

\footnotetext{
29 Ibid., 82.

30 Ibid., 83.

31 Ibid., 57.

32 Romano Guardini, Sacred Signs, trans. Grace Branham (St. Louis: Pio Decimo Press, 1956), 33.
} 
sence, originates in Him, lives in a world of divine realities, truths, mysteries and symbols, and really lives its true, characteristic, and fruitful life." ${ }^{33}$ The icon of this playfulness for Guardini is not the child per se but the artist who plays with material reality in order to express the truth of existence to the one who contemplates the work of art. ${ }^{34}$ The task of the one celebrating the liturgy is aesthetic insofar as it requires us to understand Christian life as a form of poetics, a shaping of the self into a work of art before the living God. Liturgy initiates us into purposeless activity, a festive disposition in which wasting time with God becomes normative for an account of human flourishing. The human person is not made first and foremost for activity or acquisition of experience. Rather, the "...soul needs that spiritual relaxation in which the convulsions of the will are stilled, the restlessness of struggle quietened, and the shrieking of desire silenced; and that is fundamentally and primarily the act of intention by which thought perceives truth, and the spirit is silent before its splendid majesty." 35

Can the Novus Ordo restore one to such festivity, to this playful seriousness before the reality of God? The celebration of the Novus Ordo, of course, has something to learn from the Extraordinary Form. But to claim that the Novus Ordo is intrinsically boring, incapable of producing anything like this contemplative wonder, is patently false. Catholics continue to enter this disposition through regular celebration of the Novus Ordo in parishes around the world. Those who deny this fact risk becoming akin to Guardini's aesthete, denying that the stable practice of worship even in an aesthetically beige liturgy is salvific for the human person.

Guardini, after all, was not ultimately concerned about liturgical reform. His interest was in assuming a proper contemplative disposition in the liturgical act, to let the signs and symbols of the liturgy become resonant in the life of the believer so that she can adore the living God. This task of formation or attunement of the worshipper remains unmet in our time. Culture is itself an effective ritual formation of the self, and Christian worship needs to reclaim its formative task through the restoration of a festive spirit in the act of worship.

Practically, this means two things. First, matter matters, and therefore the Novus Ordo requires immersion into a symbolic world. The Novus Ordo

\footnotetext{
${ }^{33}$ Guardini, The Spirit of the Liturgy, 66-67.

${ }^{34}$ Ibid., 69-70.

35 Ibid., 93.
} 
becomes what I call bad boring when it ceases to employ the full possibility of signs and symbols available in the liturgy. Chant, architecture, stained glass, altar pieces, incense, and frescoes are all necessary for initiating the human person into a festive disposition. Taking time for worship, allowing us to behold the wonders of God made flesh through the arts, is essential. Second, liturgical contemplation itself takes time. Rather than change the liturgy around, to focus upon reform after reform, we must attune the Christian person to see the wondrous possibility of salvation available in the stable liturgical act. This is not about focusing exclusively upon the acquisition of pleasant liturgical experiences. Rather, teaching liturgical contemplation remains a matter of fostering in men and women the capacity to see boredom not as a curse but as a gift, an invitation to a deeper wondering and desire for the Word made flesh.

\section{CONCLUSION}

In conclusion, the Novus Ordo is not boring. Boredom is a state of a subject, who has been initiated into a frenetic and anti-festive culture, which eschews stability and commitment. The task ahead is to form men and women in the Christian life who do not see disengagement as a sign of spiritual sickness but as an invitation to give up control and power and to behold the gift of existence given in the liturgical act. Such boredom is not only a good but is integral to any act of contemplation in which God is adored for His own sake rather than because of the aesthetic experiences we receive in the act of worship.

\section{BIBLIOGRAPHY}

Bauman, Zygmunt. Liquid Love: On the Frailty of Human Bonds. Malden, MA: Polity Press, 2003. Bauman, Zygmunt. Liquid Times: Living in an Age of Uncertainty. Malden, MA: Polity Press, 2007.

Bauman, Zygmunt. The Art of Life. Malden, MA: Polity Press, 2008.

Bullivant, Stephen. Mass Exodus: Catholic Disaffiliation in Britain and American since Vatican II. New York: Oxford University Press, 2019.

Carr, Nicholas. The Shallows: What the Internet Is Doing to Our Brains. New York: W.W. Norton \& Company, 2011.

Csikszentmihalyi, Mihaly. Beyond Boredom and Anxiety: Experiencing Flow in Work and Play. San Francisco: Jossey Bass, 1975.

Guardini Romano. Letters from Lake Como: Explorations in Technology and the Human Race. Grand Rapids, MI: Eerdmans, 1994.

Guardini, Romano. Sacred Signs, trans. Grace Branham. St. Louis: Pio Decimo Press, 1956. 
Guardini, Romano. The Spirit of the Liturgy, trans. Ada Lane. New York: Crossroads, 1998. Han, Byung-Chul. The Burnout Society, trans. Erik Butler. Stanford: University of Stanford Press, 2015.

Han, Byung-Chul. The Disappearance of Rituals, trans. Daniel Steuer. Malden, MA: Polity Press, 2020.

Kwasniewski, Peter. Reclaiming Our Roman Catholic Birthright: The Genius and Timeliness of the Traditional Latin Mass. Brooklyn, NY: Angelico Press, 2020.

Lacoste, Jean-Yves. Experience and the Absolute: Disputed Questions on the Humanity of Man, trans. Mark Raftery-Skehan. New York: Fordham University Press, 2004.

Lombardo, Nicholas E. "Boredom and Modern Culture." Logos 20.2(2017): 36-59.

O'Malley, Timothy P. "Liturgical Memory and Liquid Modernity." Antiphon 22(2018): 121-137.

O'Malley, Timothy P. Bored Again Catholic: How the Mass Could Save Your Life. Huntington, IN: Our Sunday Visitor, 2017.

Pieper, Josef. In Tune with the World: A Theory of Festivity. South Bend, IN: St. Augustine's Press, 1999.

Raposa, Michael L. Boredom and the Religious Imagination. Charlottesville, VA: University of Virginia Press, 1999.

Rosa, Hartmut. Resonance: A Sociology of Our Relationship to the World, trans. James C. Wagner. Malden, MA: Polity Press, 2020.

Rosa, Hartmut. Social Acceleration: A New Theory of Modernity, trans. Hartmut Rosa. New York: Columbia University Press, 2015.

Rosa, Hartmut. The Uncontrollability of the World, trans. James C. Wagner. Malden, MA: Polity, 2020.

Teresa of Avila. The Way of Perfection, trans. Kieran Kavanaugh and Otilio Rodriquez. Washington D.C.: Institute for Carmelite Studies, 2000.

Toohey, Peter. Boredom: A Lively History. New Haven: Yale University Press, 2011.

Zuboff, Shoshana. The Age of Surveillance Capitalism: The Fight for a Human Future at the New Frontiers of Power. New York: Public Affairs, 2019.

\section{ZNUDZENIE PODCZAS OFIARY LITURGICZNEJ}

St res z c z n i e

Czy istnieje coś takiego jak nudny rytuał, czy raczej nuda jest afektywnym przeżyciem podmiotu? W artykule autor stawia tezę, że nic - łącznie z posoborowymi obrzędami Kościoła - nie może być z natury nudne. Nuda - lub wyraźniej poddanie się nudzie - jest duchową chorobą późnej nowoczesności. Artykuł wychodzi od analizy zjawiska nudy, ze szczególnym uwzględnieniem nudy w jakiejś cyfrowej ekologii. Następnie zwrócono uwagę na symptomy nudy badane przez teoretyków społecznych i kulturowych w ciągu ostatniej dekady, w tym Zygmunta Baumana, Harmuta Rosę i Byung-Chul Hana. Na koniec poddano analizie Ducha liturgii Romano Guardiniego jako dającej lekarstwo na pewien rodzaj antyświątecznej kultury, która jest źródłem nudy w późnej nowoczesności. Nuda nie jest problemem związanym z obrzędem, ale ze świadomością samego człowieka, który nie nauczył się jeszcze uczestniczyć w autentycznej radości aktu kultu.

Słowa kluczowe: liturgia; kultura; świętowanie; nuda. 